\title{
Studi Perhitungan Laju Reaksi Neutron Dalam Reaktor Scwr(Supercritical Water Reactor) Model Perangkat (Assembly) Heksagonal Berbahan Bakar Thorium
}

\author{
Apriliana $^{(1)^{*}}$, Yanti Yulianti ${ }^{(1)}$, dan Pulung Karo Karo ${ }^{(1)}$ \\ (1) Jurusan Fisika FMIPA Unila, \\ Jl. Soemantri Brodjonegoro 1, Bandar Lampung 35144. \\ *E-mail: lianapril1496@gmail.com
}

Diterima (23 April 2018), Direvisi (9 Mei 2018)

\begin{abstract}
The calculation of fission and capture reaction rate with and without filter has been done using REACT of SRAC. In material 1 fission reaction rate with and without filter were increased by increasing percent of $U^{233}$. The highest fission reaction rate with filter was $5,7194 \times 10^{-2}$ reaction/ $/ \mathrm{cm}^{3}$ sand without filter was $6,1361 \times 10^{-2}$ reaction $/ \mathrm{cm}^{3}$ s. Meanwhile capture reaction rate with and without filter were decreased by increasing percent of $U^{233}$. The highest capture reaction rate with filter was $2,2156 \times 10^{-2}$ reaction/ $/ \mathrm{cm}^{3}$ s and without filter was $2,4906 \times 10^{-2}$ reaction $/ \mathrm{cm}^{3}$ s. In material 3, fission and capture reaction rate with and without filter were decreased by increasing percent of $U^{233}$ in material 1. The highest fission reaction rate with filter was $1,5218 \times 10^{-2}$ reaction $/ \mathrm{cm}^{3}$ s and without filter was $1,6293 \times 10^{-2}$ reaction $/ \mathrm{cm}^{3} \mathrm{~s}$. The highest

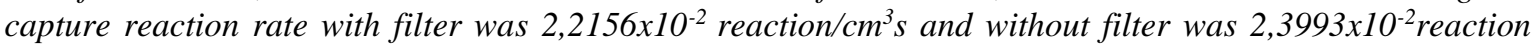
$1 \mathrm{~cm}^{3}$ s. Neutron reaction rate with filter was smaller than neutron reaction rate without filter.
\end{abstract}

Keywords: neutron reaction rate, SCWR, thorium, SRAC.

\begin{abstract}
Abstrak.Telah dilakukan perhitungan laju reaksi fisi dan reaksi penangkapan neutron dengan dan tanpa filter menggunakan kode REACT pada program SRAC.Hasil perhitungan yang diperoleh menunjukkan nilai laju reaksi fisi dengan dan tanpa filter pada material 1 mengalami kenaikan seiring dengan peningkatan persentase pengayaan $\mathrm{U}^{233}$. Nilai tertinggi laju reaksi fisi dengan filter yaitu $5,7194 \times 10^{-2}$ reaksi $/ \mathrm{cm}^{3} \mathrm{~s}$ dan tanpa filter $6,1361 \times 10^{-2}$ reaksi $/ \mathrm{cm}^{3} \mathrm{~s}$. Sedangkan nilai laju reaksi penangkapan dengan dan tanpa filter mengalami penurunan seiring peningkatan persentase pengayaan $U^{233}$. Nilai tertinggi laju reaksi penangkapan dengan filter yaitu $2,2156 \times 10^{-2}$ reaksi $/ \mathrm{cm}^{3} \mathrm{~s}$ dan tanpa filter $2,4906 \times 10^{-2}$ reaksi $/ \mathrm{cm}^{3} \mathrm{~s}$. Pada material 3, nilai laju reaksi fisi dan reaksi penangkapan neutron dengan dan tanpa filter mengalami penurunan seiring peningkatan persentase pengayaan $U^{233}$ pada material 1. Nilai tertinggi laju reaksi fisi dengan filter yaitu1,5218 $\times 10^{-2} \mathrm{reaksi} / \mathrm{cm}^{3} \mathrm{~s}$ dan tanpa filter $1,6293 \times 10^{-2} \mathrm{reaksi} / \mathrm{cm}^{3} \mathrm{~s}$. Nilai tertinggi laju reaksi penangkapan dengan filter yaitu $2,2156 \times 10^{-2}$ reaksi $/ \mathrm{cm}^{3} \mathrm{~s}$ dan tanpa filter $2,3993 \times 10^{-2} \mathrm{reaksi} / \mathrm{cm}^{3} \mathrm{~s}$. Nilai laju reaksi neutron dengan filter lebih kecil dibandingkan nilai laju reaksi neutron tanpa filter.
\end{abstract}

Kata kunci: laju reaksi neutron, SCWR, thorium, SRAC.

\section{PENDAHULUAN}

Saat ini, sumber energi listrik yang ada di Indonesia hanya terfokus pada energi fosil. Sedangkan cadangan energi fosil hanya mampu bertahan selama kurang lebih 10 tahun ke depan. Untuk mengatasi masalah kekurangan sumber energi listrik, beberapa negara telah menggunakan
Pembangkit Listrik Tenaga Nuklir (PLTN) sebagai pilihan energi alternatif. PLTN memanfaatkan energi reaktor nuklir untuk kebutuhan energi listrik. Reaktor nuklir biasanya menggunakan bahan fisil dan fertil sebagai bahan bakar. Uranium (U) alam merupakan salah satu bahan fisil yang sering digunakan sebagai bahan bakar utama sebuah reaktor nuklir. 
Selain Uranium, Thorium juga dapat digunakan sebagai bahan bakar reaktor nuklir. Thorium alam merupakan bahan fertil. Melalui serangkaian reaksi, $\mathrm{Th}^{232}$ dapat menghasilkan bahan fisil $\mathrm{U}^{233}$ [1]. Thorium terkandung dalam mineral monasit yang dapat ditemukan dalam batuan granit dari hasil sisa erosi. Sedangkan di Indonesia banyak bukit-bukit yang tersusun atas batuan sisa erosi [2].

$\mathrm{ThO}_{2}$ mempunyaikonduktivitas panas lebih tinggi dan koefisien ekspansi panas yang lebih rendah dibanding $\mathrm{UO}_{2}$, ini berakibat temperatur bahan bakar lebih rendah, yang berdampak strain lebihrendah pada kelongsong, hal ini memungkinkan bahan bakar dapat dioperasikandengan waktu tinggal yang lebih lama. Titik leleh $\mathrm{ThO}_{2}\left(3378^{\circ} \mathrm{C}\right)$ lebih tinggisekitar $500^{\circ} \mathrm{C}$ dibanding $\mathrm{UO}_{2} \quad\left(2865^{\circ} \mathrm{C}\right)$. Perbedaan temperatur ini dapatmenyediakan marjin keselamatan yang cukup apabila terjadi kenaikantemperatur akibat kehilangan pendingin (loss of coolant) [3] .

Supercritical Water Reactor (SCWR) adalah salah satu reaktor yang dirancang sebagai sumber energi listrik. Reaktor SCWR beroperasi pada temperatur dan tekanan superkritis yang akan menghilangkan proses pendidihan teras (boiling), karena pendinginannya menggunakan fase air yang sama [4].

Pada reaktor nuklir, reaksi fisi biasanya berlangsung di bahan bakar. Reaksi fisi yang terjadi harus selalu terkendali dengan nilai faktor multiplikasi efektif $\left(k_{e f f}\right)$ sama dengan 1. Hal ini menunjukkan bahwa reaktor dalam keadaan kritis [5] . Energi yang dihasilkan dari sebuah reaktor sangat bergantung pada produksi neutron dari inti reaktor [6].

Ketika merancang sebuah reaktor nuklir, maka harus diperhitungkan nilai daya yang dihasilkan. Distribusi fluks neutron yang merata akan menentukan daya reaktor [7]. Oleh sebab itu perlu dilakukannya perhitungan fluks neutron.
Seperti halnya fluks neutron, laju reaksi neutron juga perlu untuk diperhitungkan. Laju reaksi neutron yang tidak merata akan mengakibatkan pemuncakan daya pada reaktor [6].

Dengan pertimbangan pembahasan sebelumnya, maka dilakukan Studi Perhitungan Laju Reaksi Neutron dalam Reaktor SCWR (Supercritical Water Reactor) Model Perangkat (Assembly) Heksagonal Berbahan Bakar Thorium. Penelitian ini bertujuan untuk melakukan perhitungan laju reaksi neutron pada reaktor SCWR dengan memperhitungkan persentase pengayaan bahan bakar. Perhitungan laju reaksi neutron dilakukan dengan menggunakan REACT pada program Standard thermal Reactor Analysis Code (SRAC) yang dikembangkan oleh Japan Atomic Energy Research Institute (JAERI) di Japan Atomic Energy Agency (JAEA) Jepang.

\section{METODE PENELITIAN}

Penelitian ini dimulai dengan membuat desain reaktor SCWR model assembly heksagonaldengan enam pin bahan bakar berbentuk lingkaran. Setelah diperoleh desain reaktor SCWR, selanjutnya menentukan ukuran dari tiap-tiap sel. Kemudian melakukan perhitungan fraksi volume untuk mengetahui persentase setiap material yang digunakan. Besarnya fraksi volume dapat diketahui dari jari-jari tiap sel.

Kemudian menghitung nilai densitas atom dari material yang digunakan dan persentase pengayaan dari kedua bahan bakar reaktor. Densitas atom dapat dihitung dengan persamaan sebagai berikut:

$$
N=\frac{\rho N_{A}}{M}
$$

Dimana, $N=$ densitas atom $\left(\right.$ atom $\left./ \mathrm{cm}^{3}\right), \rho=$ massa jenis $\left(\mathrm{gr} / \mathrm{cm}^{3}\right), \quad N_{A}=$ bilangan 
Avogadro $\left(6,02 \times 10^{23}\right.$ atom $\left./ \mathrm{mol}\right), M=$ massa molekul (gr/mol).

Selanjutnya dilakukan perhitungan laju reaksi neutron dengan memasukkan nilai densitas atom dan pengayaan bahan bakar pada kode REACT pada program SRAC. Sistem SRAC menghitung laju reaksi menggunakan detektor dengan filter dan detektor tanpa filter dengan persamaan berikut:

$R(\vec{r})=\sum_{g=1}^{I G M A X} \Sigma_{\chi, g} \emptyset_{g}(\vec{r})$

Dengan, $R=$ laju reaksi neutron (reaksi/cm3s), $\sum_{\chi, g}=$ penampang lintang makroskopik $\left(\mathrm{cm}^{-1}\right), \emptyset_{g}=$ fluks neutron (neutron $/ \mathrm{cm}^{2} \mathrm{~s}$ ), IGMAX = jumlah grup energi.

$R(\vec{r})=\sum_{g=1}^{I G M A X} f_{g} \Sigma_{\chi, g} \emptyset_{g}(\vec{r})$

Dimana $f_{g}=$ filter transmisi faktor [8].

HASIL DAN PEMBAHASAN

\section{Desain Model Assembly Heksagonal}

Tabel 1. Fraksi volume dan ukuran sel

\begin{tabular}{cccc}
\hline Material & $\begin{array}{c}\text { Jari-jari } \\
(\mathrm{cm})\end{array}$ & $\begin{array}{c}\text { Luas } \\
\left(\mathrm{cm}^{2}\right)\end{array}$ & $\begin{array}{c}\text { Fraksi } \\
\text { volume }(\%)\end{array}$ \\
\hline Bahan bakar 1 & 1,35 & 5,7226 & 7,3222 \\
\hline Cladding 1 & 0,15 & 1,3432 & 1,7175 \\
\hline Bahan bakar 2 & 1,15 & 4,1526 & 5,3132 \\
\hline Cladding 2 & 0,15 & 1,154 & 1,4764 \\
\hline Moderator & 9,5 & 197,3547 & 84,1707 \\
\hline
\end{tabular}

Model assembly berbentuk heksagonal ditunjukkan pada Gambar 1. Model assembly heksagonal ini sesuai dengan kode IGT 12 pada SRAC [8]. Angka 1, 3, dan 5 merupakan bahan bakar $1\left(\mathrm{ThUO}_{2}\right)$ dengan persentase pengayaan $\mathrm{U}^{233} 1-5 \%$ dan luas 5,7226 $\mathrm{cm}^{2}$. Angka 7, 9, dan 11 merupakan bahan bakar $2\left(\mathrm{ThUO}_{2}\right)$ dengan persentase pengayaan $\mathrm{U}^{233} 1 \%$ dan luas 4,1526 $\mathrm{cm}^{2}$. Angka 2, 4, dan 6 merupakan cladding 1 (FeCrNi) dengan luas 1,3432 $\mathrm{cm}^{2}$, angka 8, 10, dan 12 merupakan cladding 2 (FeCrNi) dengan luas 1,154 $\mathrm{cm}^{2}$. Angka 13 sampai dengan 33 merupakan moderator atau bahan pendingin $\left(\mathrm{H}_{2} \mathrm{O}\right)$.

Fraksi volume material dan ukuran dari masing-masing sel dalam reaktor SCWR disajikan pada Tabel 1. Persentase volume ketiga sel bahan bakar 1 sebesar 7,3222\%, ketiga sel cladding 1 sebesar $1,7175 \%$, ketiga sel bahan bakar 2 sebesar 5, 3132\%, ketiga sel cladding 2 sebesar $1,4764 \%$ dan moderator $84,1707 \%$. Jumlah persentase volume dari masing-masing material adalah $100 \%$.

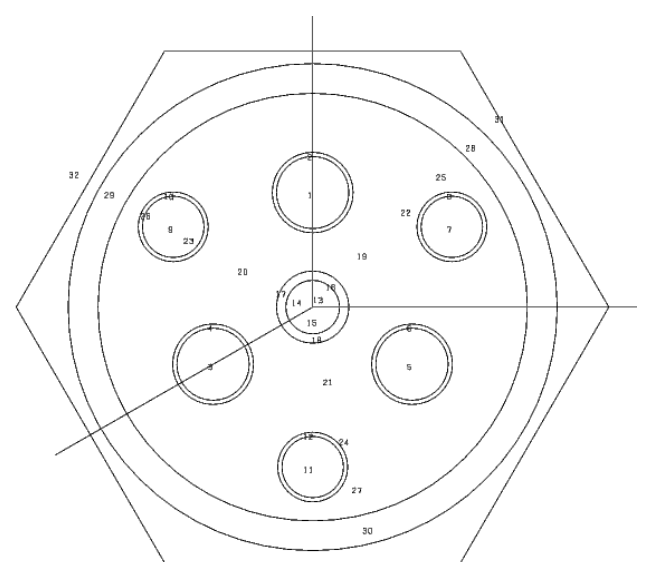

Gambar 1. Desain model assembly berbentuk heksagonal (IGT 12) 


\section{Perhitungan Laju Reaksi Neutron}

Tabel 2. Nilai laju reaksi fisi dan laju reaksi penangkapan neutron menggunakan detektor tanpa filter

\begin{tabular}{|c|c|c|c|c|c|}
\hline \multirow{2}{*}{$\begin{array}{c}\text { Pengayaan } \\
(\%)\end{array}$} & \multirow{2}{*}{$\begin{array}{c}\text { Mesh } \\
\text { ke- }\end{array}$} & \multicolumn{2}{|c|}{ Material 1 (reaksi $\left./ \mathrm{cm}^{3} \mathrm{~s}\right)$} & \multicolumn{2}{|c|}{ Material $3\left(\right.$ reaksi $\left./ \mathrm{cm}^{3} \mathrm{~s}\right)$} \\
\hline & & Fisi & Penangkapan & Fisi & Penangkapan \\
\hline \multirow{5}{*}{1} & 1 & $1,3344 \times 10^{-2}$ & $2,0408 \times 10^{-2}$ & $1,3332 \times 10^{-2}$ & $1,9612 \times 10^{-2}$ \\
\hline & 2 & $1,3617 \times 10^{-2}$ & $2,0826 \times 10^{-2}$ & $1,3605 \times 10^{-2}$ & $2,0021 \times 10^{-2}$ \\
\hline & 3 & $1,0897 \times 10^{-2}$ & $1,6768 \times 10^{-2}$ & $1,0887 \times 10^{-2}$ & $1,6030 \times 10^{-2}$ \\
\hline & 4 & $1,3666 \times 10^{-2}$ & $2,0950 \times 10^{-2}$ & $1,3654 \times 10^{-2}$ & $2,0115 \times 10^{-2}$ \\
\hline & 5 & $1,6307 \times 10^{-2}$ & $2,4906 \times 10^{-2}$ & $1,6293 \times 10^{-2}$ & $2,3993 \times 10^{-2}$ \\
\hline \multirow{5}{*}{2} & 1 & $2,3280 \times 10^{-2}$ & $1,9057 \times 10^{-2}$ & $1,1740 \times 10^{-2}$ & $1,7288 \times 10^{-2}$ \\
\hline & 2 & $2,4066 \times 10^{-2}$ & $1,9670 \times 10^{-2}$ & $1,2121 \times 10^{-2}$ & $1,7858 \times 10^{-2}$ \\
\hline & 3 & $1,9517 \times 10^{-2}$ & $1,6116 \times 10^{-2}$ & $9,8684 \times 10^{-3}$ & $1,4552 \times 10^{-2}$ \\
\hline & 4 & $2,4606 \times 10^{-2}$ & $2,0125 \times 10^{-2}$ & $1,2379 \times 10^{-2}$ & $1,8255 \times 10^{-2}$ \\
\hline & 5 & $2,9586 \times 10^{-2}$ & $2,4070 \times 10^{-2}$ & $1,4838 \times 10^{-2}$ & $2,1865 \times 10^{-2}$ \\
\hline \multirow{5}{*}{3} & 1 & $3,1068 \times 10^{-2}$ & $1,8012 \times 10^{-2}$ & $1,0500 \times 10^{-2}$ & $1,5478 \times 10^{-2}$ \\
\hline & 2 & $3,2506 \times 10^{-2}$ & $1,8790 \times 10^{-2}$ & $1,0957 \times 10^{-2}$ & $1,6162 \times 10^{-2}$ \\
\hline & 3 & $2,6880 \times 10^{-2}$ & $1,5651 \times 10^{-2}$ & $9,0697 \times 10^{-3}$ & $1,3393 \times 10^{-2}$ \\
\hline & 4 & $3,3832 \times 10^{-2}$ & $1,9536 \times 10^{-2}$ & $1,1378 \times 10^{-2}$ & $1,6795 \times 10^{-2}$ \\
\hline & 5 & $4,0895 \times 10^{-2}$ & $2,3403 \times 10^{-2}$ & $1,3695 \times 10^{-2}$ & $2,0192 \times 10^{-2}$ \\
\hline \multirow{5}{*}{4} & 1 & $3,7348 \times 10^{-2}$ & $1,7180 \times 10^{-2}$ & $9,5067 \times 10^{-3}$ & $1,4028 \times 10^{-2}$ \\
\hline & 2 & $3,9518 \times 10^{-2}$ & $1,9018 \times 10^{-2}$ & $1,0020 \times 10^{-2}$ & $1,4794 \times 10^{-2}$ \\
\hline & 3 & $3,3100 \times 10^{-2}$ & $1,5316 \times 10^{-2}$ & $8,4254 \times 10^{-3}$ & $1,2457 \times 10^{-2}$ \\
\hline & 4 & $4,1838 \times 10^{-2}$ & $1,9111 \times 10^{-2}$ & $1,0571 \times 10^{-2}$ & $1,5617 \times 10^{-2}$ \\
\hline & 5 & $5,0797 \times 10^{-2}$ & $2,2973 \times 10^{-2}$ & $1,2772 \times 10^{-2}$ & $1,8441 \times 10^{-2}$ \\
\hline \multirow{5}{*}{5} & 1 & $4,3471 \times 10^{-2}$ & $1,6401 \times 10^{-2}$ & $8,5436 \times 10^{-3}$ & $1,2622 \times 10^{-2}$ \\
\hline & 2 & $4,6578 \times 10^{-2}$ & $1,7472 \times 10^{-2}$ & $9,1032 \times 10^{-3}$ & $1,3450 \times 10^{-2}$ \\
\hline & 3 & $3,9770 \times 10^{-2}$ & $1,5057 \times 10^{-2}$ & $7,7971 \times 10^{-3}$ & $1,1543 \times 10^{-2}$ \\
\hline & 4 & $5,0298 \times 10^{-2}$ & $1,8784 \times 10^{-2}$ & $9,7848 \times 10^{-3}$ & $1,4467 \times 10^{-2}$ \\
\hline & 5 & $6,1361 \times 10^{-2}$ & $2,2668 \times 10^{-2}$ & $1,1870 \times 10^{-2}$ & $1,7521 \times 10^{-2}$ \\
\hline
\end{tabular}

Perhitungan laju reaksi neutron menujukkan jumlah reaksi neutron dengan material bahan bakar per $\mathrm{cm}^{3}$ per sekon. Program SRAC melakukan perhitungan laju reaksi fisi dan reaksi penangkapan neutron dengan menggunakan detektor neutron dengan filter berbahan Cadmium [9] dan tanpa filter. Nilai laju reaksi fisi dan reaksi penangkapan neutron menggunakan detektor tanpa filter disajikan dalam Tabel $\mathbf{2}$ dan detektor dengan filter pada Tabel 3.

Berdasarkan Tabel 2 dan Tabel 3, dapat dilihat bahwa pada material 1 nilai laju reaksi fisi neutron menggunakan detektor dengan dan tanpa filter semakin meningkat seiring dengan peningkatan persentase pengayaan $U^{233}$. Sedangkan nilai laju reaksi penangkapan neutron menggunakan detektor dengan dan tanpa filter semakin menurun sering dengan peningkatan persentase pengayaan $\mathrm{U}^{233}$. Hal ini dikarenakan $\mathrm{U}^{233}$ merupakan bahan fisil yang apabila bertemu dengan neutron akan mengalami reaksi fisi, dan $\mathrm{Th}^{232}$ merupakan bahan fertil yang mengalami reaksi penangkapan ketika bertemu dengan neutron. Pada material 3, nilai laju reaksi fisi dan reaksi penangkapan neutron menggunakan detektor dengan dan tanpa filter semakin berkurang seiring peningkatan persentase pengayaan $U^{233}$ pada material 1. 
Tabel 3. Nilai laju reaksi fisi dan laju reaksi penangkapan neutron detektor dengan filter

\begin{tabular}{|c|c|c|c|c|c|}
\hline \multirow{2}{*}{$\begin{array}{c}\text { Pengayaan } \\
(\%)\end{array}$} & \multirow{2}{*}{$\begin{array}{c}\text { Mesh } \\
\text { ke- }\end{array}$} & \multicolumn{2}{|c|}{ Material $1\left(\right.$ reaksi $\left./ \mathrm{cm}^{3} \mathrm{~s}\right)$} & \multicolumn{2}{|c|}{ Material $3\left(\mathrm{reaksi} / \mathrm{cm}^{3} \mathrm{~s}\right)$} \\
\hline & & Fisi & Penangkapan & Fisi & Penangkapan \\
\hline \multirow{5}{*}{1} & 1 & $1,2238 \times 10^{-2}$ & $1,7798 \times 10^{-2}$ & $1,2236 \times 10^{-2}$ & $1,7798 \times 10^{-2}$ \\
\hline & 2 & $1,2518 \times 10^{-2}$ & $1,8209 \times 10^{-2}$ & $1,2517 \times 10^{-2}$ & $1,8210 \times 10^{-2}$ \\
\hline & 3 & $9,7494 \times 10^{-3}$ & $1,4224 \times 10^{-2}$ & $9,7934 \times 10^{-3}$ & $1,4224 \times 10^{-2}$ \\
\hline & 4 & $1,2575 \times 10^{-2}$ & $1,8290 \times 10^{-2}$ & $1,2573 \times 10^{-2}$ & $1,8289 \times 10^{-2}$ \\
\hline & 5 & $1,5220 \times 10^{-2}$ & $2,2156 \times 10^{-2}$ & $1,5218 \times 10^{-2}$ & $2,2156 \times 10^{-2}$ \\
\hline \multirow{5}{*}{2} & 1 & $2,1407 \times 10^{-2}$ & $1,6460 \times 10^{-2}$ & $1,0703 \times 10^{-2}$ & $1,5562 \times 10^{-2}$ \\
\hline & 2 & $2,2201 \times 10^{-2}$ & $1,7071 \times 10^{-2}$ & $1,1100 \times 10^{-2}$ & $1,6144 \times 10^{-2}$ \\
\hline & 3 & $1,7707 \times 10^{-2}$ & $1,3606 \times 10^{-2}$ & $8,8531 \times 10^{-3}$ & $1,2856 \times 10^{-2}$ \\
\hline & 4 & $2,2737 \times 10^{-2}$ & $1,7483 \times 10^{-2}$ & $1,1368 \times 10^{-2}$ & $1,6534 \times 10^{-2}$ \\
\hline & 5 & $2,7658 \times 10^{-2}$ & $2,1277 \times 10^{-2}$ & $1,3828 \times 10^{-2}$ & $2,0131 \times 10^{-2}$ \\
\hline \multirow{5}{*}{3} & 1 & $2,8530 \times 10^{-2}$ & $1,5420 \times 10^{-2}$ & $9,5098 \times 10^{-3}$ & $1,3824 \times 10^{-2}$ \\
\hline & 2 & $2,9968 \times 10^{-2}$ & $1,6197 \times 10^{-2}$ & $9,9896 \times 10^{-3}$ & $1,4525 \times 10^{-2}$ \\
\hline & 3 & $2,4344 \times 10^{-2}$ & $1,3157 \times 10^{-2}$ & $8,1150 \times 10^{-3}$ & $1,1783 \times 10^{-2}$ \\
\hline & 4 & $3,1265 \times 10^{-2}$ & $1,6898 \times 10^{-2}$ & $1,0422 \times 10^{-2}$ & $1,5156 \times 10^{-2}$ \\
\hline & 5 & $3,8208 \times 10^{-2}$ & $2,0651 \times 10^{-2}$ & $1,2736 \times 10^{-2}$ & $1,8540 \times 10^{-2}$ \\
\hline \multirow{5}{*}{4} & 1 & $3,4217 \times 10^{-2}$ & $1,4598 \times 10^{-2}$ & $8,5547 \times 10^{-3}$ & $1,2432 \times 10^{-2}$ \\
\hline & 2 & $3,6375 \times 10^{-2}$ & $1,5505 \times 10^{-2}$ & $9,0943 \times 10^{-3}$ & $1,3241 \times 10^{-2}$ \\
\hline & 3 & $3,0075 \times 10^{-2}$ & $1,2826 \times 10^{-2}$ & $7,5190 \times 10^{-3}$ & $1,0916 \times 10^{-2}$ \\
\hline & 4 & $3,8632 \times 10^{-2}$ & $1,6467 \times 10^{-2}$ & $9,6587 \times 10^{-3}$ & $1,4044 \times 10^{-2}$ \\
\hline & 5 & $4,7412 \times 10^{-2}$ & $2,0202 \times 10^{-2}$ & $1,1854 \times 10^{-2}$ & $1,7254 \times 10^{-2}$ \\
\hline \multirow{5}{*}{5} & 1 & $3,9700 \times 10^{-2}$ & $1,3806 \times 10^{-2}$ & $7,6300 \times 10^{-3}$ & $1,1085 \times 10^{-2}$ \\
\hline & 2 & $4,2776 \times 10^{-2}$ & $1,4870 \times 10^{-2}$ & $8,2213 \times 10^{-3}$ & $1,1950 \times 10^{-2}$ \\
\hline & 3 & $3,6098 \times 10^{-2}$ & $1,2560 \times 10^{-2}$ & $6,9376 \times 10^{-3}$ & $1,0071 \times 10^{-2}$ \\
\hline & 4 & $4,6381 \times 10^{-2}$ & $1,6118 \times 10^{-2}$ & $8,9142 \times 10^{-3}$ & $1,2960 \times 10^{-2}$ \\
\hline & 5 & $5,7194 \times 10^{-2}$ & $1,9860 \times 10^{-2}$ & $1,0992 \times 10^{-2}$ & $1,5998 \times 10^{-2}$ \\
\hline
\end{tabular}
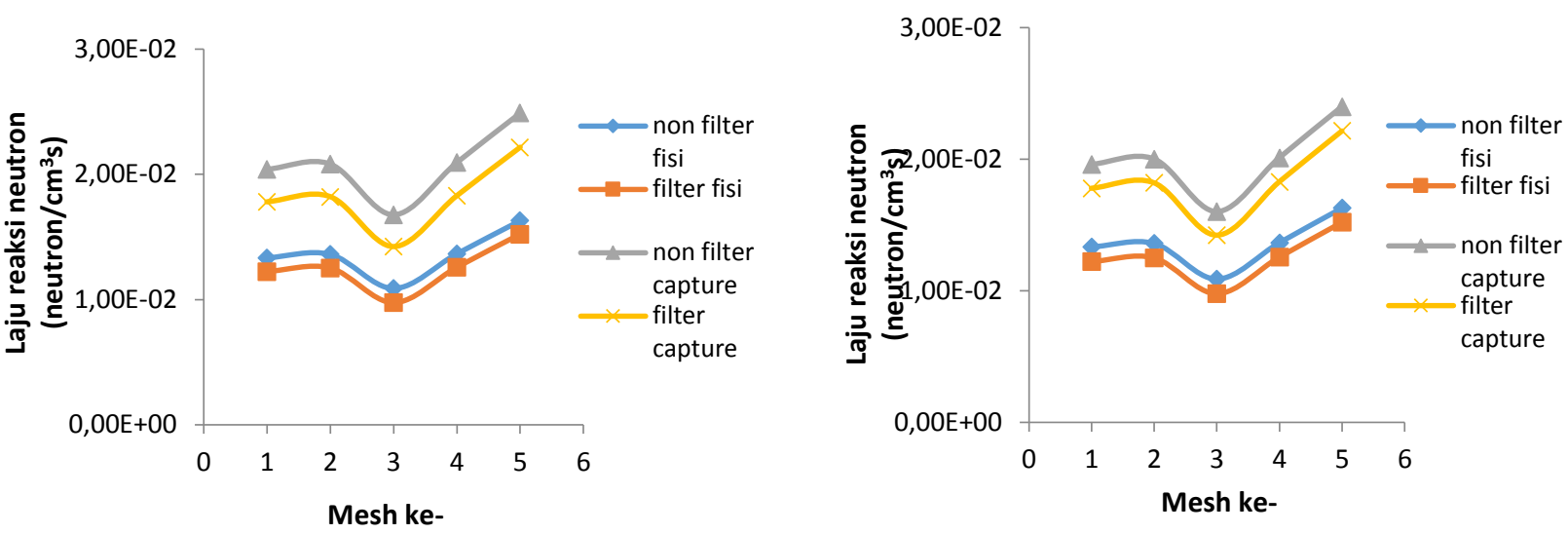

Gambar 2. Perbandingan laju reaksi neutron menggunakan detektor tanpa filter dan detektor dengan filter pada pengayaan $1 \%$ (a.) material 1 (b.) material 3

Gambar 2 (a) pada material 1. Dapat dilihat bahwa nilai laju reaksi fisi dan reaksi penangkapan neutron menggunakan detektor tanpa filter memiliki puncak yang lebih tinggi dibandingkan nilai laju reaksi fisi dan reaksi penangkapan neutron menggunakan detektor dengan filter.
Gambar 2 (b) pada material 3. Nilai laju reaksi fisi dan reaksi penangkapan neutron menggunakan detektor tanpa filter memiliki puncak yang lebih tinggi dibandingkan nilai laju reaksi fisi dan reaksi penangkapan neutron menggunakan detektor dengan filter. 


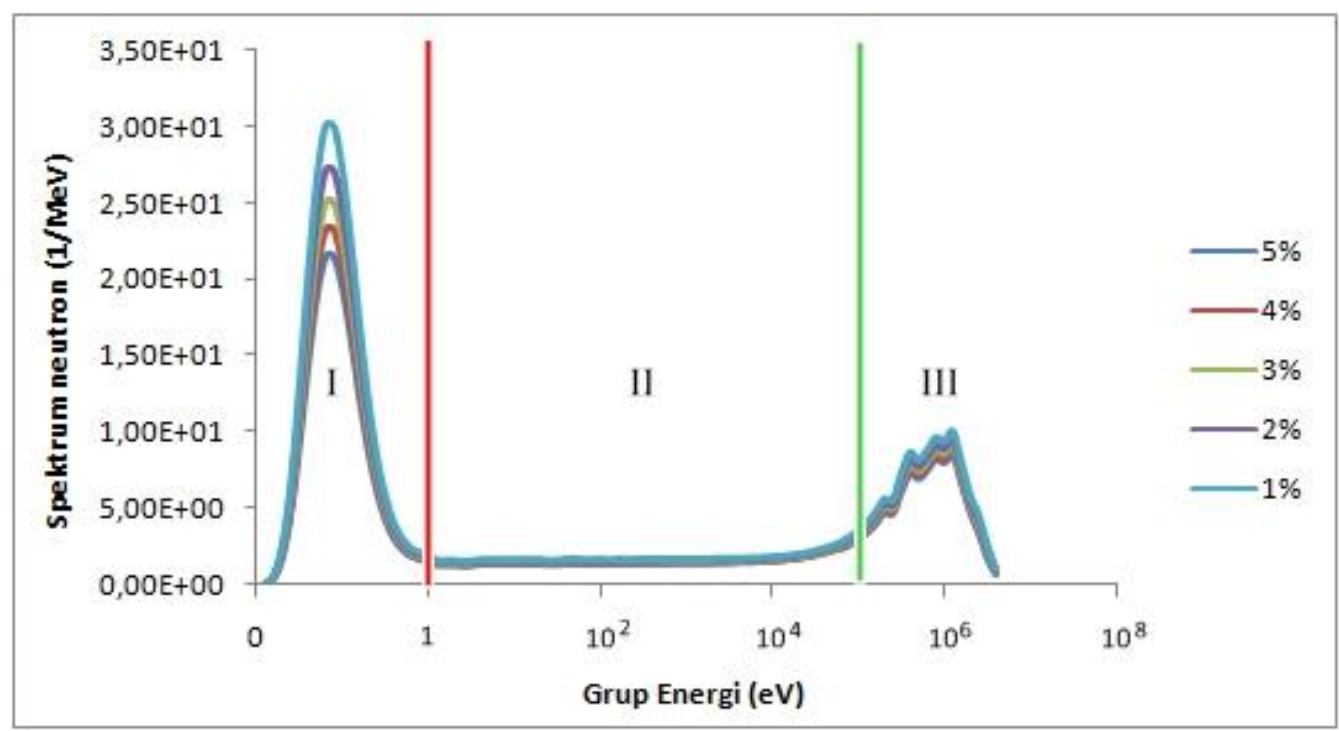

Gambar 3. Spektrum neutron pada pengayaan $U^{233} 1-5 \%$

Hal ini dikarenakan filter pada detektor neutron merupakan Cadmium yang memiliki kemampuan menyerap neutron yang tinggi.

Spektrum neutron merupakan besaran yang menyatakan jumlah neutron persatuan energi. Rentang energi neutron dalam reaktor nuklir terbagi ke dalam tiga daerah, yaitu neutron termal (I), neutron epitermal (II), dan neutron cepat (III) [10]. Spektrum neutron dari reaktor SCWR pada penelitian ini ditunjukkan pada Gambar 3.

Pada Gambar 3, dapat dilihat bahwa spektrum neutron termal mendominasi reaktor SCWR pada penelitian ini dengan nilai $30 \mathrm{MeV}^{-1}$ pada pengayaan $1 \%$. Hal ini dikarenakan $\mathrm{Th}^{232}$ memiliki nilai penampang serapan neutron termal yang tinggi. Sedangkan spektrum neutron pada daerah epitermalmemiliki bentuk yang hampir mendatar dan sedikit naik. Hal ini menunjukkan bahwa proses perlambatan neutron dengan proses tangkapan dan fisi neutron mengalami kompetisi yang sangat besar [11]. Pada ketiga daerah tersebut, bentuk grafik spektrum neutron untuk pengayaan 1 sampai dengan 5\% memiliki bentuk yang sama, dan tinggi yang hampir sama. Hal ini dikarenakan jenis bahan bakar yang digunakan pada reaktor SCWR ini merupakan bahan bakar yang sama yaitu campuran $\mathrm{Th}^{232}$ dan $\mathrm{U}^{233}$. Nilai spektrum neutron pada pengayaan $1 \%$ memiliki nilai yang lebih besar dibandingkan dengan pengayaan 2 sampai 5\%. Hal ini dikarenakan $\mathrm{U}^{233}$ yang memiliki kemampuan serap neutron yang tinggi [11].

\section{KESIMPULAN}

Pada material 1, nilai laju reaksi fisi menggunakan detektor dengan dan tanpa filter mengalami peningkatan seiring dengan meningkatnya nilai persentase pengayaan $\mathrm{U}^{233}$.Nilai tertinggi laju reaksi fisi neutron tanpa filter yaitu6,1361 $\times 10^{-}$ ${ }^{2}$ reaksi $/ \mathrm{cm}^{3} \mathrm{~s}$, dan nilai tertinggi laju reaksi fisi neutron dengan filter yaitu $5,7194 \times 10^{-}$ ${ }^{2}$ reaksi $/ \mathrm{cm}^{3} \mathrm{~s}$. Sedangkan nilai laju reaksi penangkapan neutron menggunakan detektor dengan dan tanpa filter mengalami penurunan seiring dengan meningkatnya persentase pengayaan $\mathrm{U}^{233}$.Nilai tertinggi laju reaksi penangkapan neutron tanpa filter yaitu $2,4906 \times 10^{-2} \mathrm{reaksi} / \mathrm{cm}^{3}$ s, dan nilai tertinggi laju reaksi penangkapan neutron dengan filter tertinggi 2,2156× $10^{-2}$ reaksi $/ \mathrm{cm}^{3} \mathrm{~s}$. 
Pada material 3, nilai laju reaksi fisi dan reaksi penangkapan neutron menggunakan detektor dengan dan tanpa filter mengalami penurunan seiring dengan meningkatnya persentase pengayaan $\mathrm{U}^{233}$ pada material 1.Nilai tertinggi laju reaksi fisi neutron tanpa filteryaitu $1,6293 \times 10^{-}$ ${ }^{2}$ reaksi $/ \mathrm{cm}^{3} \mathrm{~s}$, dan nilai tertinggilaju reaksi fisi neutron dengan filter yaitu $1,5218 \times 10^{-}$ ${ }^{2}$ reaksi $/ \mathrm{cm}^{3} \mathrm{~s}$. Nilai tertinggi laju reaksi penangkapan neutron tanpa filter yaitu $2,3993 \times 10^{-2} \mathrm{reaksi} / \mathrm{cm}^{3} \mathrm{~s}$, dan nilai tertinggi laju reaksi penangkapan neutron dengan filter yaitu2,2156x $10^{-2}$ reaksi $/ \mathrm{cm}^{3} \mathrm{~s}$. Nilai laju reaksi fisi dan reaksi penangkapan neutron tanpa filter lebih besar dibandingkan nilai laju reaksi fisi dan reaksi penangkapan neutron dengan filter.Spektrum energi neutron termal mendominasi reaktor SCWR dengan nilai puncak $30 \mathrm{MeV}^{-1}$.

\section{DAFTAR PUSTAKA}

[1] M., Ariani, F., Supardi, Monado, \& Z. Su'ud. "Potensi Thorium Sebagai Bahan Bakar pada Reaktor Cepat Berpendingin Gas untuk PLTN". Prosiding Semirata 2015 bidang MIPA BKS-PTN Barat. pp 39-45.

[2] H., Ngadenin. K.S., Syaeful, I.G., Widana, Sukadana, \& F.D. Indrastomo. "Studi Potensi Thorium pada Batuan Granit di Pulau Bangka. Jurnal Pengembangan Energi Nuklir". Vol 16. No 2. pp 143-155. 2014.

[3] E., Dewita, "Analisis Potensi Thorium Sebagai Bahan Bakar Nuklir Alternatif PLTN". Jurnal Pengembangan Energi Nuklir. Vol 14. No1. pp 45-56. 2012.
[4] Y.D., Anggoro, D., Dewi, Nurlaila \& A.T., Yuliyanto. "Kajian Perkembangan PLTN Generasi IV". Jurnal Pengembangan Energi Nuklir. Vol 15. No 2. pp69-79. 2013.

[5] D.Y., Tadeus, B. Setiyono, \& I. Setiawan. "Simulasi Kendali Daya Reaktor Nuklir dengan Teknik Kontrol Optimal". Jurnal Universitas Diponegoro Transmisi12. Vol 12. No 1. pp 8-13. 2010.

[6] R., Martha, M.A. Shafii, \& Afdal. "Analisis Laju Reaksi Neutron dalam Sel Bahan Bakar Nuklir pada Reaktor Cepat. Jurnal Ilmu Fisika (JIF). Vol 8. No 2. pp 70-77. 2016.

[7] M.A., Shafii, Perhitungan Penampang Lintang Mikroskopik dalam Sel Bahan Bakar Nuklir. Spektra: Jurnal Fisika dan Aplikasinya. Vol 16. No 1. pp 23-27. 2015.

[8] T., Okumura, K., Kugo, Kaneko \& $\mathrm{K}$., Thuchihashi. "The comprehensive neutronics calculation code system." Japan. JAEA. pp 1-28. 2002.

[9] G. F., Knoll, "Radiation Detection and Measuremen"t. John Wiley and Sons. Singapore. 1989.

[10] W.M., Stacey, "Nuclear Reactor Physics". John Wiley \& Sons Inc. New York. 2001.

[11] P. I., Yazid, Perhitungan Spektrum Energi Fluks Neutron Reaktor TRIGA 2000 Bandung. Jurnal Sains dan Teknologi Nuklir Indonesia. Vol IV. pp 45-46. 2003. 
Apriliana Dkk.: Studi Perhitungan Laju Reaksi Neutron Dalam Reaktor Scwr(Supercritical Water Reactor) Model Perangkat(Assembly) Heksagonal Berbahan Bakar Thorium 